\title{
An optimal defense strategy for phenolic glycoside production in Populus trichocarpa - isotope labeling demonstrates secondary metabolite production in growing leaves
}

\author{
Tara Joy Massad ${ }^{1,3}$, Susan E. Trumbore ${ }^{1}$, Gantsetseg Ganbat ${ }^{1}$, Michael Reichelt ${ }^{2}$, Sybille Unsicker ${ }^{2}$, \\ Andreas Boeckler ${ }^{2}$, Gerd Gleixner ${ }^{1}$, Jonathan Gershenzon ${ }^{2}$ and Steffen Ruehlow ${ }^{1}$
}

${ }^{1}$ Max Planck Institute for Biogeochemistry, Hans-Knöll-Str. 10, 07745 Jena, Germany; ${ }^{2}$ Max Planck Insitute for Chemical Ecology, Hans-Knöll-Str. 8 , 07745 Jena, Germany; ${ }^{3}$ Instituto de

Química, Universidade de São Paulo, Av. Prof. Lineu Prestes 748, Bloco 11T (Sala 1124), São Paulo, SP 05508-000, Brazil

\section{Author for correspondence: \\ Tara Joy Massad \\ Tel: +5511951791281 \\ Email: tmassad77@gmail.com}

Received: 12 November 2013

Accepted: 11 March 2014

New Phytologist (2014) 203: 607-619

doi: 10.1111/nph.12811

Key words: carbon allocation, isotope labeling, optimal defense, phenolic glycoside, salicinoid, secondary metabolite, tradeoff.

\section{Summary}

- Large amounts of carbon are required for plant growth, but young, growing tissues often also have high concentrations of defensive secondary metabolites. Plants' capacity to allocate resources to growth and defense is addressed by the growth-differentiation balance hypothesis and the optimal defense hypothesis, which make contrasting predictions. Isotope labeling can demonstrate whether defense compounds are synthesized from stored or newly fixed carbon, allowing a detailed examination of these hypotheses.

- Populus trichocarpa saplings were pulse-labeled with ${ }^{13} \mathrm{CO}_{2}$ at the beginning and end of a growing season, and the ${ }^{13} \mathrm{C}$ signatures of phenolic glycosides (salicinoids), sugars, bulk tissue, and respired $\mathrm{CO}_{2}$ were traced over time. Half of the saplings were also subjected to mechanical damage.

- Populus trichocarpa followed an optimal defense strategy, investing ${ }^{13} \mathrm{C}$ in salicinoids in expanding leaves directly after labeling. Salicinoids turned over quickly, and their production continued throughout the season. Salicin was induced by early-season damage, further demonstrating optimal defense.

- Salicinoids appear to be of great value to $P$. trichocarpa, as they command new $C$ both early and late in the growing season, but their fitness benefits require further study. Export of salicinoids between tissues and biochemical pathways enabling induction also needs research. Nonetheless, the investigation of defense production afforded by isotope labeling lends new insights into plants' ability to grow and defend simultaneously.

\section{Introduction}

Secondary metabolites can divert significant amounts of fixed carbon (C) from other plant functions. For example, up to $20 \%$ of foliar DW in young aspen is composed of phenolic glycosides (Donaldson et al., 2006). In addition to being important C sinks, secondary metabolites enable long-term $\mathrm{C}$ gain by protecting photosynthetic tissues from herbivory (e.g. tannins, Coley, 1986; terpenes, Gershenzon \& Dudareva, 2007; phenolic glycosides, Boeckler et al., 2011). Because secondary metabolites involved in herbivore resistance often represent large resource investments (Gershenzon, 1994), many studies suggest that their production leads to reductions in fitness, particularly in the absence of herbivores (Redman et al., 2001; Strauss et al., 2002; Hare et al., 2003; Züst et al., 2011). However, defenses do not always incur an allocation cost (Neilson et al., 2013), although the results of such studies may be influenced by variation in genetic backgrounds and environmental conditions (Herms \& Mattson, 1992; Koricheva, 2002). The concept of allocation costs forms the basis of the growth-differentiation balance hypothesis (GDBH), which states that, at the level of the whole organism, plants experience a tradeoff between growth and defense that results in either submaximal growth rates in populations that evolved an emphasis on defense production in response to high herbivore pressure or low investments in defense in populations that evolved in resource-rich environments where competition is intense. Within plants, however, different tissues or 'modules' may act as carbon sources or sinks and be differentially defended (Herms \& Mattson, 1992). Defense investments in unique tissues and at the whole-organism level therefore remain an active area of research for understanding resource prioritization in plants. The present work examines the ability of growing plant tissues to invest in defense by following carbon allocation to primary and secondary metabolites using stable isotopes.

The environmental constraint model (Bryant et al., 1988) and the GDBH (Herms \& Mattson, 1992) suggest that plants evolving under abundant resource conditions and intense competition should delay defense investment until the demands of growth are 
met. In spite of this prediction, fast-growing species in the genus Populus maintain high concentrations of phenolic glycosides from spring into mid-summer, and some genotypes actually have higher concentrations earlier in the year (Osier et al., 2000; Holeski et al., 2012). In addition, species of this genus are known to have their highest concentrations of phenolics (Meyer \& Montgomery, 1987) and phenolic glycosides (Kleiner et al., 2003) in young, developing leaves. Phenolic glycosides are known to be important as antiherbivore defenses and have been shown to have a diversity of effects, from deterring mammalian feeding to limiting the growth rate of generalist caterpillars (Hwang \& Lindroth, 1997; Osier \& Lindroth, 2001; Boeckler et al., 2011). These data support the optimal defense hypothesis $(\mathrm{ODH})$, which proposes that plants with an evolutionary history of high herbivory prioritize secondary metabolite production, even at the expense of growth (McKey, 1974; Rhoades, 1979). The defense of young leaves is also predicted by the $\mathrm{ODH}$, as immature leaves are of greater value to a plant, representing more potential lifetime carbon assimilation than older leaves.

Metabolic turnover of defenses will also influence their cost to a plant, and whether or not phenolic glycosides are continuously synthesized or static within a leaf remains an open question. Kleiner et al. (1999) examined phenolic glycoside turnover in Populus deltoides using ${ }^{14} \mathrm{C}$ labeling and found evidence of turnover in sink but not source leaves. A second approach to this question used an inhibitor to block the activity of phenylalanine ammonia-lyase, an enzyme required for phenolic glycoside synthesis. No change in mature leaf salicin or salicortin content was subsequently detected, suggesting that these compounds do not turn over in mature leaves (Ruuhola \& Julkunen-Tiitto, 2000). Because of such discrepancies, the present work also addresses the question of turnover by measuring changes in phenolic glycoside concentrations and stable isotope composition over time.

The inducibility of defenses also affects their 'net' value, that is, the amount of resources preserved from herbivory minus resources diverted from growth. Phenolic glycosides in Populus tremuloides are known to be induced following herbivory, but this is a variable phenomenon. Induction is also compound-specific; for example, in some species salicin was induced, but not salicortin, whereas in others salicortin increased with herbivory, but not salicin (Clausen et al., 1989; Osier \& Lindroth, 2001; Ruuhola et al., 2001; Stevens \& Lindroth, 2005; Fields \& Orians, 2006). Previous work with Populus maximowiczii $\times$ nigra L. showed that stem removal was related to a decrease in starch and sucrose and an increase in salicin, indicating that salicin is induced without clarifying whether increased production is from new or stored C (Tschaplinski \& Blake, 1994). This diversity of responses suggests that induction varies in the benefits it offers to a plant and may incur costs similar to those of constitutively produced defenses (Agrawal et al., 2002). With a mechanical damage treatment, the present study further explores the inducibility of phenolic glycosides, as well as the origin of carbon in induced vs constitutively produced salicin and salicortin.

All of these factors affecting the cost of defense and the existence of a tradeoff between primary and secondary metabolites could be addressed by studying the origin of the carbon involved in the synthesis of these compounds. In order to facilitate both growth and defense, plants may invest recently assimilated carbon into primary metabolites early in a growing season but rely on stored reserves to supply demands for defenses or vice versa. This possibility can be explored using carbon isotope labeling as a tool to understand fine-scale carbon allocation. Several studies have employed isotope analyses to detect the origin and lifetime of primary and secondary metabolites within leaves (Mihaliak et al., 1991; Gershenzon et al., 1993; Baldwin et al., 1994), and isotope studies tracking changes in defense production throughout the development of a leaf can provide valuable details to explain resource allocation in plants (Mooney \& Chu, 1974). In addition, isotope labeling allows an examination of $\mathrm{C}$ allocation to primary and secondary metabolites in different tissues. For example, phenolic glycosides are also present in Populus stems and roots (Lindroth et al., 2007; Harding et al., 2009; Boeckler et al., 2013). Because phenolic compounds serve as antibrowsing defenses (Bryant, 1981; Lindroth \& St Clair, 2013), more C might be allocated to increase their presence in bark late in the growing season, in order to protect against winter browsing. In terms of primary metabolites, stress from the loss of leaf tissue limits the amount of sugar transported to fine roots (Kosola et al., 2002), and C flow to roots in damaged and undamaged plants can likewise be studied with isotope labeling.

This work contributes to studies on growth-defense tradeoffs and turnover and induction of defenses by measuring the ${ }^{13} \mathrm{C}$ allocated to primary metabolites and two phenolic glycoside secondary metabolites ('salicinoid' is chemically a more correct term for phenolic glycosides; Boeckler et al., 2011) in isotopically labeled Populus trichocarpa early and late in one growing season, in combination with a mechanical damage treatment to simulate herbivory. In doing so, the following hypotheses are addressed:

- Stored carbon supplies early growing season secondary metabolite production; late-season secondary metabolites rely on recently assimilated carbon.

- Salicinoid concentrations will be highest in young leaves and decline as leaves mature. Salicinoid concentrations in mature leaves will remain constant throughout the growing season.

- Salicinoids are stable once produced (no turnover), indicating a lower overall cost of production for the plant.

- Plants suffering mechanical damage will induce the production of higher concentrations of salicinoids in immature and mature leaves using newly assimilated carbon. Early-season mechanical damage will have more of an effect on induction than late-season damage, because it more severely limits the plants' photosynthetic potential.

\section{Materials and Methods}

Monoclonal cuttings of Populus trichocarpa were obtained from the Thüringer Landesanstalt für Landwirtschaft, Dornburg, TH, Germany. $P$. trichocarpa is a fast-growing species native to western North America. Cuttings were individually planted in 21 pots with potting soil (Klasmann KKS Bio Topfsubstrat 27) mixed 1:1 with quartz sand in April 2010 and grown in the glasshouse with additional light (Son-T Agro 430 W HPS bulbs, primary light range $=520-610 \mathrm{~nm}$, Philips Lighting Co., 
Somerset, NJ, USA) from 06:00 to 17:00 h. The pots were uniformly watered with an irrigation system that delivered water two to three times for 3 min between 12:00 and 13:00 h each day, depending on the temperature. In October 2010, the plants were moved to a climate chamber and exposed to $5 \mathrm{~d}$ of gradual cooling followed by an artificial winter of $8 \mathrm{~h}, 10^{\circ} \mathrm{C}$ days and $4^{\circ} \mathrm{C}$ nights to induce senescence and leaf fall. The plants were returned to the glasshouse in January and exposed to the previous light and water conditions.

On 24 April 2011, as leaves were flushing, plants were exposed to ${ }^{13} \mathrm{CO}_{2}$ in a closed-system labeling chamber (1969.1 1; built at Siegman Koch, Germany, and adapted at the Max Planck Institute for Biogeochemistry). A total of 23-25 plants were labeled at a time on three consecutive days (72 individuals total) for $c .2 \mathrm{~h}$ from 12:00 to 14:00 h. Before introduction of ${ }^{13} \mathrm{CO}_{2}$ into the chamber, the chamber was flushed with $\mathrm{CO}_{2}$-free air until the concentration of $\mathrm{CO}_{2}$ was between 45 and $80 \mathrm{ppm}$. At that point, $400 \mathrm{ppm} \mathrm{CO}_{2}$ were introduced into the chamber via acidification of $2.67 \mathrm{~g} 99 \% \mathrm{NaH}^{13} \mathrm{CO}_{3}$ (Euriso-Top, Saarbrücken, Germany) with $\mathrm{HCl}$. The ${ }^{13} \mathrm{CO}_{2}$ was cycled through the chamber, and its concentration and uptake were monitored with a Raman spectrometer (Institute of Photonic Technology, Jena, Germany; Frosch etal., 2013). After the labeled $\mathrm{CO}_{2}$ was depleted to $200 \mathrm{ppm}$, in general after $1 \mathrm{~h}$, another $200 \mathrm{ppm}$ ${ }^{13} \mathrm{CO}_{2}$ were added in the same manner (acidification of $1.33 \mathrm{~g}$ $99 \% \mathrm{NaH}^{13} \mathrm{CO}_{3}$ ). When the plants had completely absorbed all the ${ }^{13} \mathrm{CO}_{2}$, after $2 \mathrm{~h}$ total in the chamber, the chamber was opened and the plants were returned to the glasshouse. Photosynthetically active radiation in the growth chamber was measured at the beginning of labeling and directly after opening the chamber door with a Li-Cor 250 light meter (Li-Cor, Lincoln, NE, USA); on average it was $192.6 \mu \mathrm{mol} \mathrm{m} \mathrm{m}^{-2}$. The plants were randomly shifted on the glasshouse tables weekly to avoid any effects of positioning within the glasshouse.

One hour after labeling, 30 individuals were exposed to a mechanical damage treatment, in which $10 \%$ of their total leaf area was removed by cutting whole leaves across the base near the petiole. Leaves were selected for cutting such that undamaged leaves remained both above and below the damage. These individuals were kept in a second glasshouse to ensure no volatile signaling would induce defense production in the undamaged plants. Six hours after labeling, respiration samples were collected from six individuals with and six individuals without damage to measure the amount of ${ }^{13} \mathrm{CO}_{2}$ respired. Four respiration samples were taken from single leaves or terminal groups of several small leaves enclosed in dark branch bags (made by covering airtight plastic bags with duct tape) over the course of $30 \mathrm{~min}$, and samples were analyzed with late-season gas chromatography-isotoperatio mass spectrometry (GC-IRMS) to construct Keeling plots (Keeling, 1958), in order to obtain the amount of ${ }^{13} \mathrm{CO}_{2}$ respired. Respiration samples continued to be collected on the same individuals every $24 \mathrm{~h}$ for $7-9 \mathrm{~d}$, and then every $48 \mathrm{~h}$ for $1 \mathrm{wk}$, and every 3-5 d for the remainder of the month. Respiration samples were also collected at 2 and 3 months post-labeling.

Three individuals from both the mechanical damage treatment and the undamaged control treatment were harvested $6 \mathrm{~h}$ after labeling for metabolite analysis. Leaves, bark, and roots were removed and flash-frozen in liquid nitrogen. Samples were directly freeze-dried (Gamma 1-20; Martin Christ Gefriertrocknungsanlagen, Osterode am Harz, Germany), ground in a Wiley Mill (Thomas Scientific, Swedesboro, NJ, USA), and stored at $-20^{\circ} \mathrm{C}$. Leaves were separated upon collection into mature and immature leaves located above or below the damaged leaves or from branches without herbivore damage. Immature leaves were not fully expanded or lignified. Three individuals from both the mechanical damage and control treatments were also harvested at $24 \mathrm{~h}, 1 \mathrm{wk}$, and 1 month after labeling. Respiration samples were also collected on all individuals at the time of harvesting.

On 17 and 18 August, late-season ${ }^{13} \mathrm{C}$ labeling was done for the 42 remaining plants using the same procedure as described earlier. Half of these plants were also subjected to the $10 \%$ mechanical damage treatment $1 \mathrm{~h}$ after labeling. Respiration and whole-plant samples were collected in the same manner as for the first labeling. Plants were harvested at $6 \mathrm{~h}$ post-labeling, $24 \mathrm{~h}$ post-labeling, and 1 and $2 \mathrm{wk}$ post-labeling. The last samples were collected $2 \mathrm{wk}$ after labeling because leaves were beginning to senesce. At each collection point, plants were completely sacrificed, so data from each time period come from separate individuals. In addition to the labeled plants, three unlabeled plants grown under the same glasshouse conditions as the labeled plants (they were not placed in the labeling chamber) were sampled at the end of the experiment to determine average ${ }^{13} \mathrm{C}$ concentrations of unlabeled tissue, metabolites, and respired $\mathrm{CO}_{2}$.

\section{Salicinoid extractions and measurements}

Salicinoids were extracted from all tissues harvested at $6 \mathrm{~h}, 24 \mathrm{~h}$, $1 \mathrm{wk}, 1 \mathrm{month}$, and $2 \mathrm{wk}$ after the first and second labeling events. Twenty milligrams of freeze-dried ground plant material were weighed into $1 \mathrm{ml}$ tubes in a 96 tube tray. One milliliter of $\mathrm{MeOH}$ with phenyl $\beta$-D-glucopyranoside as an internal standard $\left(0.2 \mathrm{mg} \mathrm{ml}^{-1}\right)$ was added to each sample. Samples were extracted by shaking with ball bearings on a paint shaker and mixing on a plate shaker at room temperature for $30 \mathrm{~min}$. Samples were centrifuged, and $800 \mu \mathrm{l}$ of extracted samples were removed from the extraction tubes. Samples were re-extracted by adding $500 \mu \mathrm{l}$ $\mathrm{MeOH}$ to the plant material and following the same procedure. The second extraction $(480 \mu \mathrm{l})$ was added to the first, and samples were stored at $4{ }^{\circ} \mathrm{C}$ until they were run on the high-performance liquid chromatography (HPLC). Samples were analyzed by HPLC on an Agilent HP1100 Series instrument equipped with a Nucleodur Sphinx RP column (Macherey-Nagel, Düren, Germany, $250 \times 4.6 \mathrm{~mm}$ i.d., $5 \mu \mathrm{m}$ particle size) by using a water (solvent A) and acetonitrile (solvent B) gradient at a flow rate of $1 \mathrm{ml} \mathrm{min}^{-1}$ at $25^{\circ} \mathrm{C}$ (injection volume $20 \mu \mathrm{l}$ ). The gradient was as follows: $14 \% \mathrm{~B}$ (start), $14-58 \% \mathrm{~B}$ (22 $\mathrm{min}), 58-100 \% \mathrm{~B}$ (0.1 min), $100 \%$ B (2.9 min), 100-14\% B (0.1 min), and 14\% B ( $4.9 \mathrm{~min})$. The eluent was monitored by diode array detection between 190 and $360 \mathrm{~nm}(2 \mathrm{~nm}$ interval). Salicinoids were identified based on a comparison of retention times and UV absorption spectra with those of authentic standards (salicin was purchased from Sigma-Aldrich, and salicortin was kindly provided by Dr 
Richard Lindroth, University of Wisconsin, USA). Final results were calculated from peak areas relative to the internal standard at $200 \mathrm{~nm}$ using response factors determined from a dilution series of pure compounds; results are presented as $\mathrm{mg} \mathrm{mg}^{-1} \mathrm{DW}$.

Pure fractions of salicin and salicortin were collected via HPLC separation coupled to a fraction collector (SF2120, Advantec, Pleasanton, CA, USA). These samples were dried and resuspended in $1 \mathrm{ml}$ water. ${ }^{13} \mathrm{C}$ content was measured via a Finnigan LC IsoLink system (Thermo Electron Corporation, Bremen, Germany) with an HPLC coupled to an isotope ratio mass spectrometer (Finnigan Surveyor HPLC with MS pump, Thermo Electron Corporation; DELTAplusXP MS, Thermo Finnigan GmbH, Germany; following Hettmann et al., 2007). Samples $(100 \mu l)$ were injected by an autosampler (Finnigan Surveyor autosampler, Thermo Electron), and all carbon from the samples was converted by wet chemical combustion to $\mathrm{CO}_{2}$ that was transferred online for isotope ratio determination following Scheibe et al. (2012).

\section{Sugar extractions and measurements}

Glucose, fructose, and sucrose were analyzed to compare changes in the concentrations and ${ }^{13} \mathrm{C}$ incorporation of basic primary metabolites with those of the salicinoids. Sucrose is synthesized from glucose and fructose following the assimilation of newly acquired $\mathrm{C}$ into triose phosphates during the Calvin cycle and is the dominant form of carbohydrate that is transported between plant tissues (Taiz \& Ziegler, 2002). These three sugars were therefore selected for a comparison of ${ }^{13} \mathrm{C}$ incorporation into primary and secondary metabolites.

Sugars were extracted from $100 \mathrm{mg}$ of dried, ground plant material in $20 \mathrm{ml}$ EtOH: $\mathrm{H}_{2} \mathrm{O}$ as described in Richter et al. (2009). Briefly, the extract was cleaned with anion and cation solid phase extraction cartridges (AG@50W-X8 and AG@1-X8, Bio$\mathrm{Rad}$ ) and analyzed with liquid chromatography-IRMS to determine the concentration and isotope ratios of the sugars. Individual sugars were separated from samples (20 $\mu \mathrm{l}$ injection volume) on an HPLC column (Nucleogel Sugar 810Ca, Macherey-Nagel, Diiren, Germany). The HPLC was operated at $85^{\circ} \mathrm{C}$; the eluent was HPLC-grade water, and the flow rate was $0.5 \mathrm{ml} \mathrm{min}^{-1}$.

\section{Bulk material ${ }^{13} \mathrm{C}$ measurements}

Ground plant material was weighed $(0.8-1.0 \mathrm{mg})$ into Sn capsules (97.5\% purity, IVA, Germany) to measure bulk ${ }^{13} \mathrm{C}$ content following the methods of Qi et al. (2003). A Delta C prototype isotope ratio mass spectrometer, modified at the Max Planck Institute for Biogeochemistry to meet specifications for a Delta+ (Finnigan MAT, Bremen, Germany) was used for bulk measurements. The instrument was coupled to a EA 1100 (CE, Milan, Italy) via a ConFlo III for bulk analysis (http://www.bgc-jena.mpg.de/service/ iso_gas_lab/pmwiki/pmwiki.php/IsoLab/TheInstruments).

\section{Data analysis}

Metabolite concentrations Changes in the concentrations of metabolites and bulk material were analyzed with mixed model
MANOVA. Comparisons were made for early and late growing season samples separately. For early-season samples, the concentrations of sugars and salicinoids were compared in models including the tissue type (immature leaves, mature leaves, bark, and roots), mechanical damage treatment, and time after labeling in fully crossed models. Nonsignificant interactions were removed and best-fit models are presented. The identities of individual seedlings were included as random effects, because multiple samples came from the same seedling (i.e. leaves, bark, and roots). Late-season models included salicinoid concentrations only, as sugar concentrations were not measured late in the growing season. Immature leaves were also not present late in the growing season. The mechanical damage treatment late in the growing season included plants with early-season damage (directly after the first labeling event), late-season damage (directly following the second labeling event), and no damage.

Metabolites from leaf material were also analyzed without bark and root samples so that the interactions between leaf maturity and location relative to the mechanical damage could be analyzed. Predictors in fully crossed models for early-season data therefore included leaf maturity, location relative to mechanical damage (above, below, from a separate branch, no damage), and time after labeling. Late-season models only examined the location relative to mechanical damage and time after all leaves were mature. Data were checked for normality and homogeneity of variance with the Shapiro-Wilk test and Levene test in SAS (SAS/STAT ${ }^{\circledR}$ Software 9.2; Cary, NC, USA) and were transformed for normality as needed. MANOVA models were run in $\mathrm{R}$ using the Car package (Fox et al., 2013).

C allocation and turnover Because both the concentration of a compound and its isotopic composition may change following labeling, we defined the total amount of labeled $\mathrm{C}$ allocated to defense compounds as follows. Sucrose in mature leaf tissue $6 \mathrm{~h}$ after labeling represented the highest concentration of ${ }^{13} \mathrm{C}$ label incorporated in plant tissues (Supporting Information, Fig. S1). We therefore calculated the fraction of label C incorporated into other metabolites compared with the initial sucrose ${ }^{13} \mathrm{C}:{ }^{12} \mathrm{C}$ ratio in leaves $\left({ }^{13} \mathrm{C}:{ }^{12} \mathrm{C}=6.5\right)$. Using this equation (Eqn 1), the amount of labeled $\mathrm{C}$ in sucrose at $6 \mathrm{~h}$ post-labeling is, by definition, 1.0, and the other data have values between 0 and 1 depending on whether they are unlabeled $(0)$ or have ${ }^{13} \mathrm{C}$ signatures close to the maximum incorporation.

The total amount of labeled $\mathrm{C}$ in a given metabolite is then given as the amount of the metabolite times the fraction of labeling. For each metabolite measured in the HPLC-purified extract:

$$
\begin{aligned}
& \text { Total amount of labeled } \mathrm{C} \text { in the metabolite } \\
& =\frac{{ }^{13} \mathrm{C} /{ }^{12} \mathrm{C} \text { labeled extract }-{ }^{13} \mathrm{C} /{ }^{12} \mathrm{C} \text { unlabeled extract }}{} \\
& \quad \times \text { extract concentration }
\end{aligned}
$$

Eqn 1

Note that, when we express the amount of labeled $\mathrm{C}$ in the metabolite in this way, declines in the label with time can be caused by reductions in either the ${ }^{13} \mathrm{C}:{ }^{12} \mathrm{C}$ ratio (i.e. dilution by 
unlabeled $\mathrm{C}$ fixed after the labeling or remobilization of stored ${ }^{12} \mathrm{C}$ ) or the concentration of the metabolite, or both.

The amount of ${ }^{13} \mathrm{C}$ in the metabolites calculated as described earlier was analyzed with repeated-measures mixed model ANOVA based on plant tissue, mechanical damage, and time since labeling as in the models for metabolite concentrations. ANOVA was used rather than MANOVA because datasets for the ${ }^{13} \mathrm{C}$ values of the metabolites were not all equally balanced.

Similar to the analyses for concentrations, fully crossed models were first tested and then simplified until the best-fit model was found. Individual seedlings were again incorporated as random effects, and data were log-transformed for normality as needed. In addition, leaf material was analyzed separately in order to look for differences in ${ }^{13} \mathrm{C}$ incorporation in leaves above, below, or on separate branches from the mechanical damage treatment. The incorporation of ${ }^{13} \mathrm{C}$ in bulk tissue and the ratio of ${ }^{13} \mathrm{C}:{ }^{12} \mathrm{C}$ in respired $\mathrm{CO}_{2}$ were also analyzed with mixed model ANOVA. Bulk material and respired $\mathrm{CO}_{2}$ were analyzed as absolute ${ }^{13} \mathrm{C}:{ }^{12} \mathrm{C}$ ratios rather than being adjusted based on the sucrose end member. Data were log-transformed for homogeneity of variances, and the mixed model ANOVAs were run using Proc Mixed and Proc GLM in SAS.

To examine turnover time in sugars and salicin and salicortin, the fraction of label $\mathrm{C}$ in the metabolites was compared between collection periods. Short-term (fast turnover; 6-24 h post-labeling) and longer-term (slow turnover; $24 \mathrm{~h}$ to 1 month post-labeling early in the season or $24 \mathrm{~h}$ to $2 \mathrm{wk}$ late in the season) changes in ${ }^{13} \mathrm{C}$ incorporation were examined to determine potentially fast and slow turnover using Eqn 2, as follows:

Turnover time $=\frac{\left(t_{1}-t_{2}\right)}{\log _{\mathrm{e}}\left(\mathrm{C}_{t_{2}}\right) / \log _{\mathrm{e}}\left(\mathrm{C}_{t_{1}}\right)}$

Eqn 2

where $t_{1}$ and $t_{2}$ are the number of $\mathrm{h}$ post-labeling. $\mathrm{C}_{t \mathrm{x}}$ refers to the fraction of labeled $\mathrm{C}$ in the metabolites at those times. ${ }^{13} \mathrm{C}$ in the different metabolites may cycle both quickly (the fast turnover pool) and more slowly (the slow turnover pool). This difference is based on how labile the different sources of $\mathrm{C}$ used in metabolite synthesis are (Carbone \& Trumbore, 2007). Because saplings were sacrificed at each harvesting period, the time series is based on comparisons of individuals, randomly matched, rather than differences within a single individual. Differences in turnover time were examined with traditional ANOVA with Proc GLM in SAS; data were log-transformed for normality when necessary.

\section{Results}

\section{Metabolite concentrations - variation in defense production between plant tissues, across the growing season, and in response to mechanical damage}

Early in the growing season, the concentrations of both primary and secondary metabolites were higher in leaves than in bark and roots. Concentrations of the salicinoids, salicin and salicortin, together represented c. $1-2 \%$ of leaf dry mass, with salicin concentrations higher in immature leaves and salicortin concentrations higher in mature leaves. All metabolites except sucrose were affected by the mechanical damage treatment (Table 1; Fig. S2). Glucose and fructose concentrations were greater in all tissues $24 \mathrm{~h}$ after mechanical damage (Figs S3, S4). Salicin in immature leaves increased $24 \mathrm{~h}$ after artificial damage. In mature leaves, salicin increased more quickly, and concentrations were elevated 6 and $24 \mathrm{~h}$ after damage. Salicin concentrations were also higher in bark and roots from damaged plants 1 wk after mechanical damage (Fig. 1a). Salicortin concentrations were more variable, but were overall higher in tissues from undamaged plants (Fig. 1b).

There was no evidence of salicinoid induction late in the growing season, but concentrations of salicin and salicortin differed depending on the type of tissue from which they were extracted (Table 2). Salicin was at its highest concentration in leaves, and salicortin was equally high in leaves and bark (Fig. 2a,b). Salicortin concentrations were higher in bark late in the growing season relative to early measurements (late $\approx 0.014 \mathrm{mg} \mathrm{mg}^{-1}$, early $\approx 0.012 \mathrm{mg} \mathrm{mg}^{-1}$ ), but concentrations in roots were lower late in the season (late $\approx 0.008 \mathrm{mg} \mathrm{mg}^{-1}$, early $\approx 0.01 \mathrm{mg} \mathrm{mg}^{-1}$ ) and roughly equal (though slightly lower) in leaves (late $\approx 0.0137 \mathrm{mg} \mathrm{mg}^{-1}$, early $\approx 0.0143 \mathrm{mg} \mathrm{mg}^{-1}$ ). By contrast, salicin was reduced in all tissue types late in the growing season (e.g. early leaves $\approx 0.0024 \mathrm{mg} \mathrm{mg}^{-1}$, late leaves $\approx 0.0013 \mathrm{mg}$ $\left.\mathrm{mg}^{-1}\right)$. Further analyses examining extracts from leaves in response to the location of the leaf relative to the mechanical damage treatment did not reveal additional significant differences.

Table 1 Mixed model MANOVA results for comparisons of the concentrations of Populus trichocarpa metabolites early in the growing season in response to the type of tissue from which they were extracted, the mechanical damage treatment, and time after the plants were labeled and damaged. The best-fit model is presented

\begin{tabular}{|c|c|c|c|c|c|}
\hline \multicolumn{4}{|c|}{ Complete MANOVA model results } & \multicolumn{2}{|c|}{ Responses of individual dependent variables } \\
\hline Predictor & $F$ & df & $P$ & Response & Significant predictors at $P<0.05$ \\
\hline Tissue & 19.0 & $15 / 291$ & $<0.0001$ & Glucose & Tissue, mechanical damage $\times$ time \\
\hline Mechanical damage & 3.4 & $5 / 95$ & 0.007 & Fructose & Tissue, mechanical damage $\times$ time \\
\hline Time & 3.3 & $15 / 291$ & $<0.0001$ & Sucrose & Tissue \\
\hline Mechanical damage $\times$ time & 2.8 & $15 / 291$ & 0.0004 & $\begin{array}{l}\text { Salicin } \\
\text { Salicortin }\end{array}$ & $\begin{array}{l}\text { Tissue, mechanical damage, time, mechanical damage } \times \text { time } \\
\text { Tissue, mechanical damage, mechanical damage } \times \text { time }\end{array}$ \\
\hline
\end{tabular}


(a)

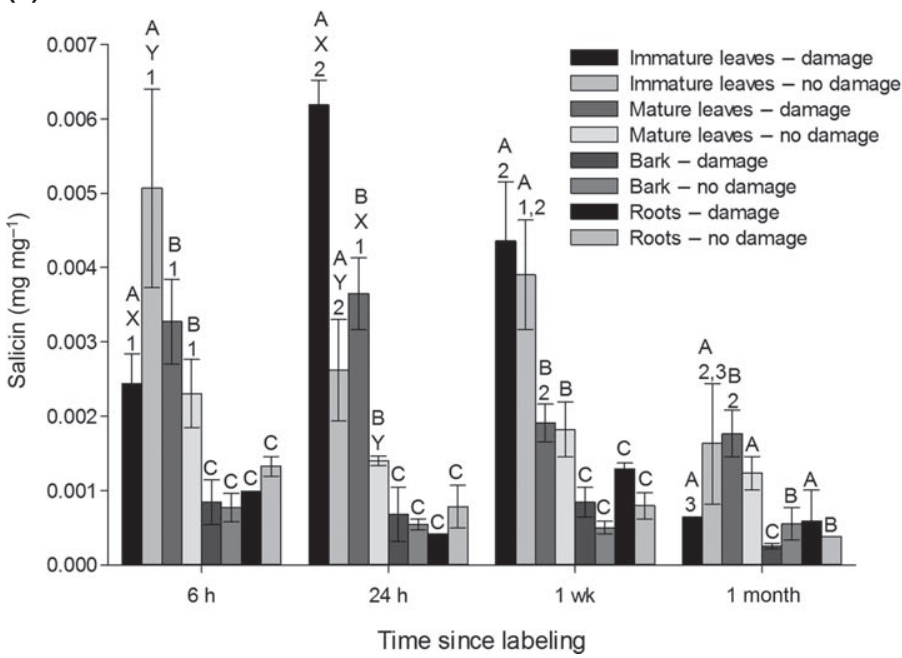

(b)

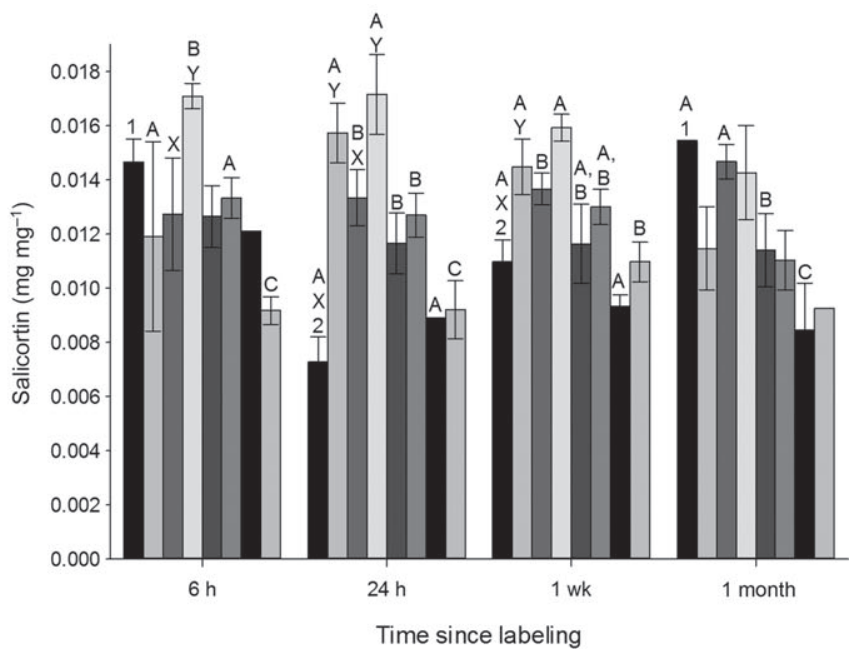

Fig. 1 Mean salicin (a) and salicortin (b) concentrations from Populus trichocarpa early in the growing season. The letters A-C denote significant differences between tissues within each level of mechanical damage treatment and time period. The letters $X$ and $Y$ represent significant differences in the mechanical damage treatment for a given tissue type and time period. The numbers indicate significant differences between time periods for a given tissue and level of mechanical damage treatment. For example, salicin concentrations in immature leaves differed at $6 \mathrm{~h}(\mathrm{~A})$ from concentrations in mature leaves (B), bark (C) and roots (C) for both levels of mechanical damage treatment. Immature leaves from damaged plants had significantly more salicin (X) than those from undamaged plants $(Y)$ at $24 \mathrm{~h}$ post-labeling. Salicin concentration also differed in immature leaves with and without damage between 6 ( 1 ) and $24 \mathrm{~h}$ (2) after labeling. Error bars, \pm SE.

Table 2 Mixed model MANOVA results for comparisons of the concentrations of Populus trichocarpa phenolic glycosides late in the growing season in response to the type of tissue from which they were extracted, the only significant factor in the model. No late-season sugar data are available

\begin{tabular}{|c|c|c|c|c|c|}
\hline \multicolumn{4}{|c|}{ Complete MANOVA model results } & \multicolumn{2}{|c|}{$\begin{array}{l}\text { Responses of individual } \\
\text { dependent variables }\end{array}$} \\
\hline Predictor & $F$ & $\mathrm{df}$ & $P$ & Response & $\begin{array}{l}\text { Significant predictors } \\
\text { at } P<0.05\end{array}$ \\
\hline Tissue & 31.0 & $4 / 256$ & $<0.0001$ & $\begin{array}{l}\text { Salicin } \\
\text { Salicortin }\end{array}$ & $\begin{array}{l}\text { Tissue } \\
\text { Tissue }\end{array}$ \\
\hline
\end{tabular}

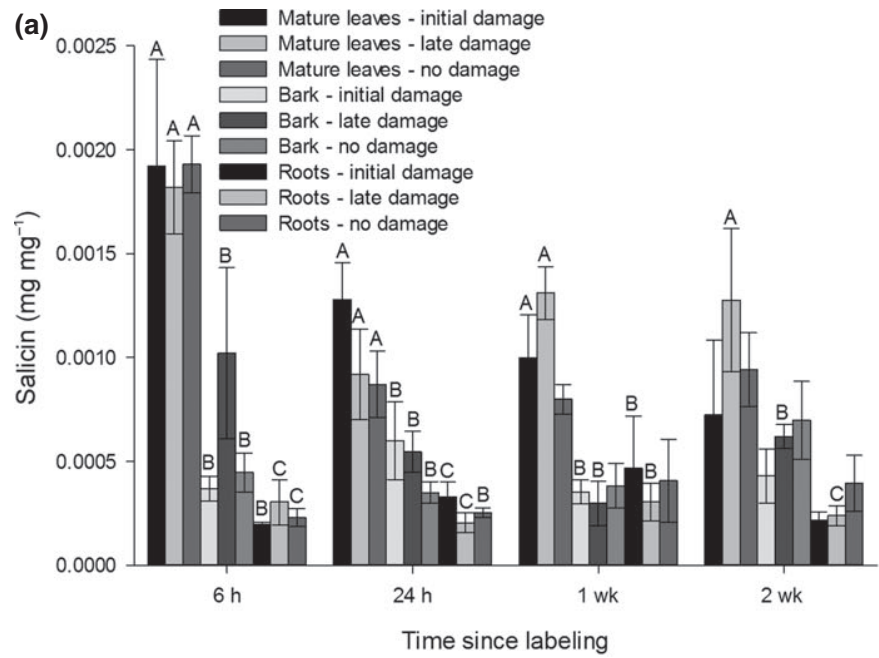

\section{${ }^{13} \mathrm{C}$ incorporation - the origin of $\mathrm{C}$ in primary and secondary metabolites}

Newly assimilated $\mathrm{C}$ was allocated to plant defense compounds directly after labeling, even in growing leaves (Figs 3, 4). Analyses of ${ }^{13} \mathrm{C}:{ }^{12} \mathrm{C}$ in metabolites early in the growing season also showed that the mechanical damage treatment altered the allocation of label $\mathrm{C}$ in salicinoids but not in sugars.

Bulk tissue and respired $\mathrm{C}$ The amount of ${ }^{13} \mathrm{C}$ in bulk tissue depended on the type of tissue and the amount of time after labeling both early and late in the growing season (Table 3). ${ }^{13} \mathrm{C}$ in bulk material declined in leaves with time after labeling, but it

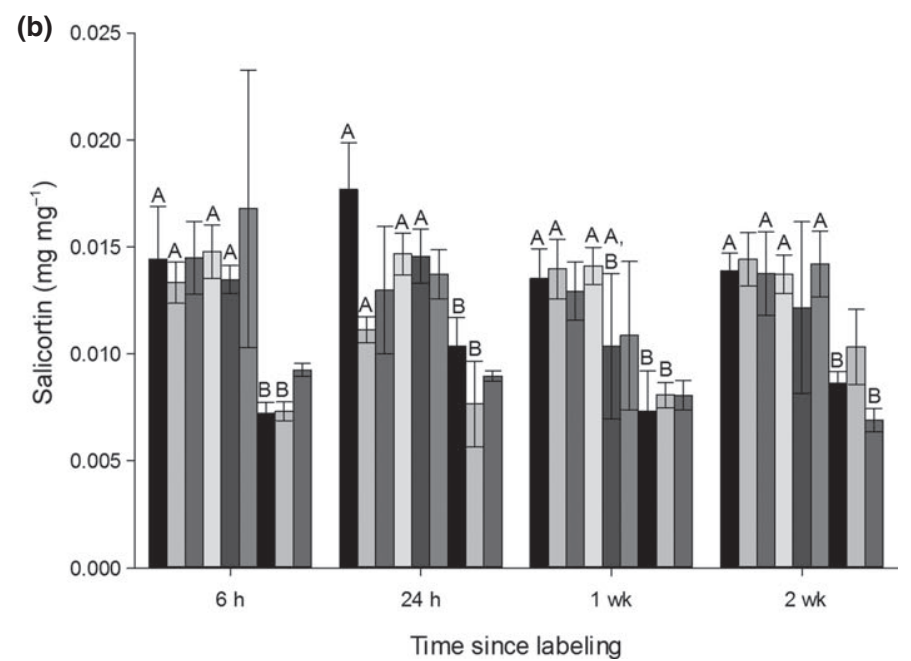

Fig. 2 Mean salicin (a) and salicortin (b) concentrations from Populus trichocarpa late in the growing season. The only significant differences were between tissues (indicated by letters). Error bars, $\pm \mathrm{SE}$. 
(a)

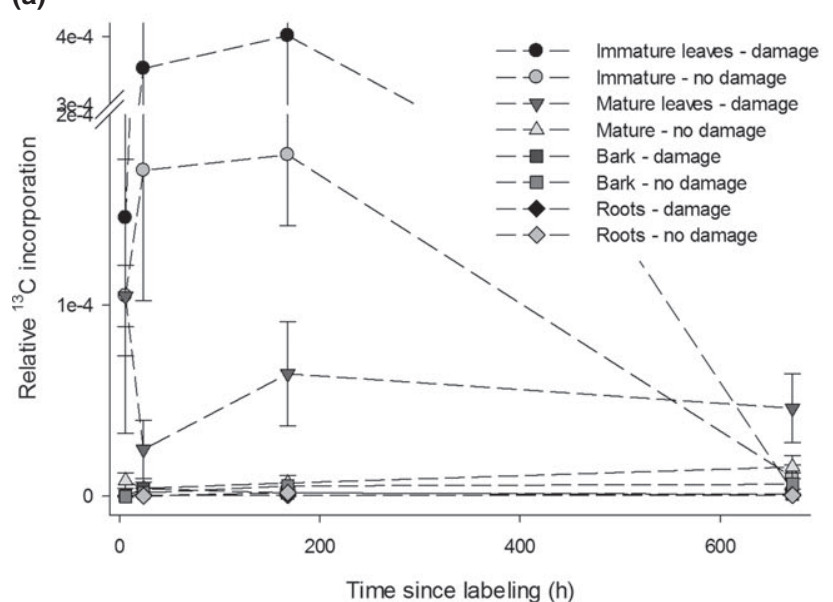

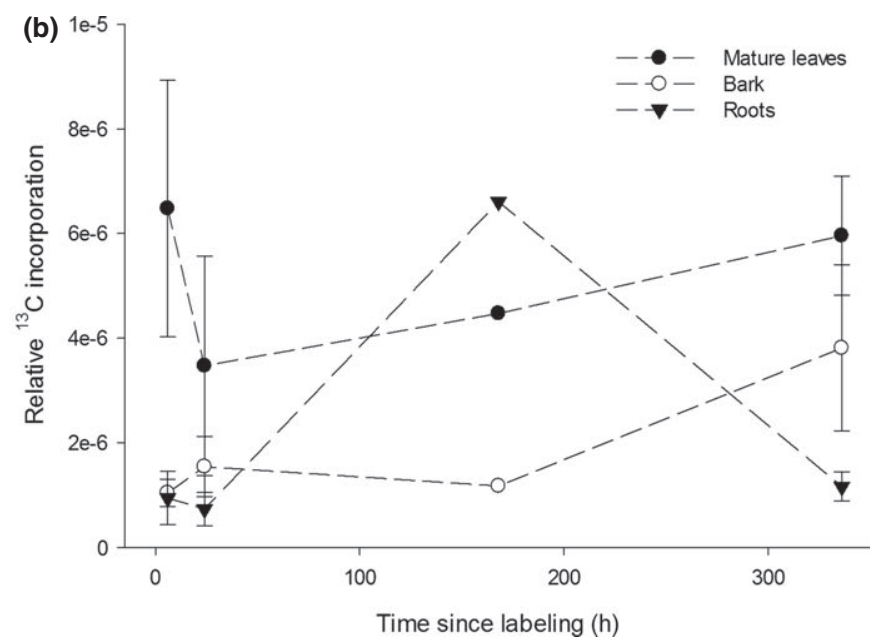

Fig. 3 Mean ${ }^{13} \mathrm{C}$ incorporation in salicin from Populus trichocarpa early (a) and late (b) in the growing season. Relative ${ }^{13} \mathrm{C}$ incorporation is based on the fraction of ${ }^{13} \mathrm{C}$ in salicin compared with the initial sucrose ${ }^{13} \mathrm{C}:{ }^{12} \mathrm{C}$ ratio (Eqn 1). There are significant differences between tissues and as a result of mechanical damage early in the season; late in the season, only tissue type is significant. Error bars, $\pm \mathrm{SE}$.
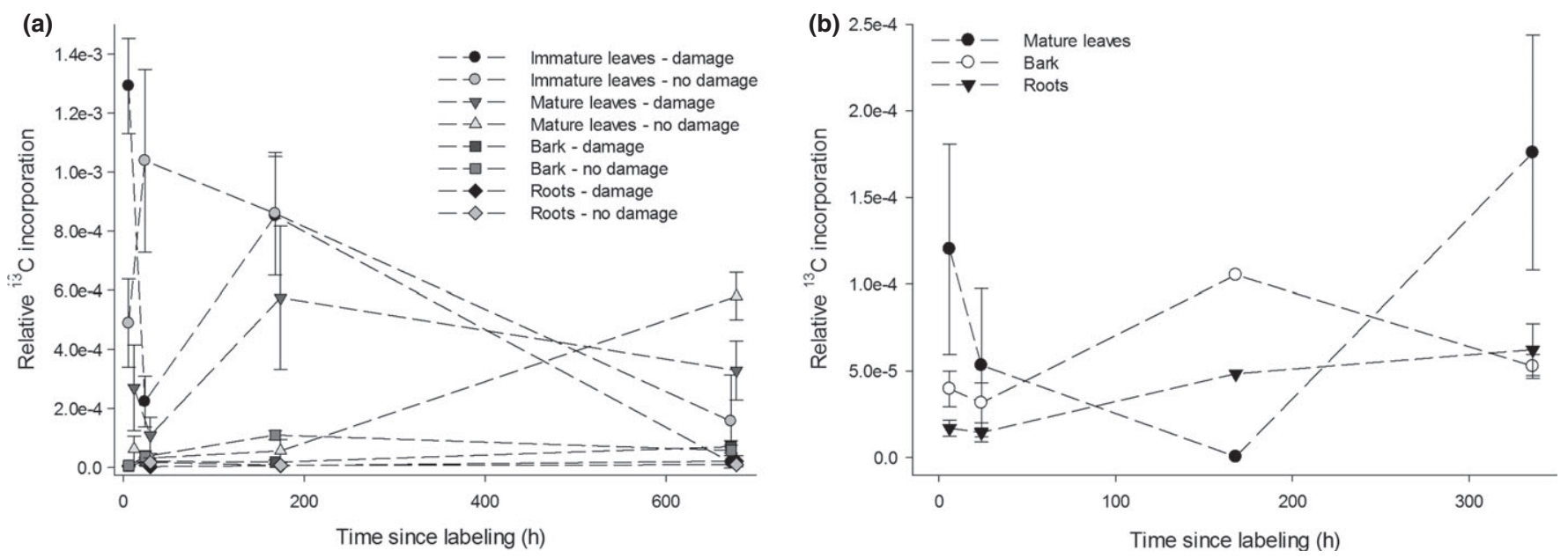

Fig. 4 Mean ${ }^{13} \mathrm{C}$ incorporation in salicortin from Populus trichocarpa early (a) and late (b) in the growing season. Relative ${ }^{13} \mathrm{C}$ incorporation is based on the fraction of ${ }^{13} \mathrm{C}$ in salicortin compared with the initial sucrose ${ }^{13} \mathrm{C}:{ }^{12} \mathrm{C}$ ratio (Eqn 1). There are significant interactions among the type of tissue, the mechanical damage treatment, and time early in the season; late in the season, only tissue type is significant. Error bars, \pm SE.

Table $3{ }^{13} \mathrm{C}:{ }^{12} \mathrm{C}$ ratio in bulk tissue of Populus trichocarpa. Tissue type, time after labeling, and the mechanical damage treatment were included in fully crossed mixed models. The best-fit models are presented

\begin{tabular}{lrll}
\hline & $F$ & df & $P$ \\
\hline $\begin{array}{l}\text { Early season (AIC =178.4) } \\
\quad \text { Tissue }\end{array}$ & 98.6 & $3 / 49.4$ & $<0.0001$ \\
$\quad$ Time & 12.0 & $3 / 25.0$ & $<0.0001$ \\
$\quad$ Tissue $\times$ time & 8.8 & $9 / 72.8$ & $<0.0001$ \\
Late season (AIC = 336.7) & & & \\
$\quad$ Tissue & 35.9 & $2 / 30.3$ & $<0.0001$ \\
Time & 0.1 & $3 / 32.8$ & 0.96 \\
Tissue $\times$ time & 7.8 & $6 / 57.5$ & $<0.0001$ \\
\hline
\end{tabular}

AIC, Akaike information criterion.

peaked in bark and roots at $24 \mathrm{~h}$ post-labeling and then declined. Early in the growing season, the amount of ${ }^{13} \mathrm{C}$ at 1 month postlabeling was highest in mature leaves. By the end of the experiment, the amount of ${ }^{13} \mathrm{C}$ was highest in mature leaves and roughly equal in other tissues (Fig. S5a,b).

The ratio of ${ }^{13} \mathrm{C}:{ }^{12} \mathrm{C}$ in respired $\mathrm{C}$ was only affected by time after labeling, dropping quickly between 6 and $24 \mathrm{~h}$ post-labeling (Table 4; Fig. S6a,b).

Sugars The mechanical damage treatment did not affect the incorporation of the ${ }^{13} \mathrm{C}$ label into glucose, fructose, or sucrose, but there were significant changes with time and the type of tissue examined (Table 5). Sucrose had far more label C than the other sugars, and the amount was highest in mature and immature leaves $6 \mathrm{~h}$ post-labeling. After $24 \mathrm{~h},{ }^{13} \mathrm{C}$ concentrations dropped greatly; in mature leaves, for example, the change was from $45.4 \pm 5.5 \mu \mathrm{g} \mathrm{mg}^{-1}$ label C at $6 \mathrm{~h}$ to $12.4 \pm 2.4 \mu \mathrm{g} \mathrm{mg}^{-1}$ at $24 \mathrm{~h}$ (see Fig. $\mathrm{S} 1$ for the ratio of ${ }^{13} \mathrm{C}:{ }^{12} \mathrm{C}$ in sucrose). In glucose, the highest amounts of label $\mathrm{C}$ were measured in all tissues at $24 \mathrm{~h}$ after labeling, and most ${ }^{13} \mathrm{C}$ was found in immature leaves 
Table 4 Respired ${ }^{13} \mathrm{C}$ from Populus trichocarpa. Tissue type (immature vs mature leaves), time after labeling, and the mechanical damage treatment were included in fully crossed mixed models early in the growing season. Late in the growing season, time and the mechanical damage treatment were analyzed. The best-fit models are presented

\begin{tabular}{llll}
\hline & $F$ & $\mathrm{df}$ & $P$ \\
\hline $\begin{array}{l}\text { Early season (AIC = -16.0) } \\
\text { Time }\end{array}$ & 63.1 & $13 / 115$ & $<0.0001$ \\
$\begin{array}{l}\text { Late season (AIC = 31.9) } \\
\quad \text { Time }\end{array}$ & 24.5 & $8 / 20.2$ & $<0.0001$ \\
\hline
\end{tabular}

AIC, Akaike information criterion.

Table $5{ }^{13} \mathrm{C}:{ }^{12} \mathrm{C}$ ratio in sugars from Populus trichocarpa early in the growing season. Tissue type, time after labeling, and the mechanical damage treatment were included in fully crossed mixed models. The best-fit models are presented

\begin{tabular}{lrll}
\hline & $F$ & $\mathrm{df}$ & $P$ \\
\hline Glucose (AIC= 321.7) & & & \\
$\quad$ Tissue & 58.2 & $3 / 41.3$ & $<0.0001$ \\
$\quad$ Time & 14.2 & $3 / 20.9$ & $<0.0001$ \\
$\quad$ Tissue $\times$ time & 7.7 & $9 / 65.3$ & $<0.0001$ \\
Fructose (AIC=200.3) & & & \\
$\quad$ Tissue & 75.8 & $3 / 51.2$ & $<0.0001$ \\
$\quad$ Time & 18.0 & $3 / 21.4$ & $<0.0001$ \\
$\quad$ Tissue $\times$ time & 8.6 & $9 / 65.6$ & $<0.0001$ \\
Sucrose (AIC=361.6) & & & \\
$\quad$ Tissue & 43.7 & $3 / 35.9$ & $<0.0001$ \\
$\quad$ Mechanical damage & 0.9 & $1 / 17.9$ & 0.4 \\
$\quad$ Time & 48.3 & $3 / 18$ & $<0.0001$ \\
$\quad$ Tissue $\times$ time & 12.6 & $9 / 58.9$ & $<0.0001$ \\
\hline AlC Akaike information citer & & & \\
\end{tabular}

AIC, Akaike information criterion.

followed by mature leaves (Fig. S7). The increase in label C at $24 \mathrm{~h}$ in immature leaves was related to the high concentration of glucose in immature leaves from plants with mechanical damage at that time; the ${ }^{13} \mathrm{C}:{ }^{12} \mathrm{C}$ ratio itself was actually highest in immature leaves at $6 \mathrm{~h}$ post-labeling (compare Fig. S7 with Fig. S8 to see the difference between the total label $\mathrm{C}$ and the ${ }^{13} \mathrm{C}:{ }^{12} \mathrm{C}$ ratio).

In fructose, the highest amount of label $\mathrm{C}$ was in immature leaves $6 \mathrm{~h}$ after labeling (Fig. S9), and label $\mathrm{C}$ in fructose peaked in all other tissues at $24 \mathrm{~h}$ post-labeling.

Salicin Just $6 \mathrm{~h}$ after labeling, label $\mathrm{C}$ was present in salicin in leaves, and the amount of label $\mathrm{C}$ allocated to salicin was higher in immature than in mature leaves (Table 6; Fig. 3a). Immature leaves from saplings with mechanical damage had the highest amount of label $\mathrm{C}$ allocated to their production, and salicin in mature leaves from plants with damage also contained more ${ }^{13} \mathrm{C}$ than did salicin from mature leaves from undamaged plants. ${ }^{13} \mathrm{C}$ peaked after $1 \mathrm{wk}$ in immature leaves. In mature leaves from damaged plants, ${ }^{13} \mathrm{C}$ peaked after $6 \mathrm{~h}$; in mature leaves from undamaged plants, ${ }^{13} \mathrm{C}$ peaked 1 month after labeling. In bark and roots, the incorporation of label $\mathrm{C}$ into salicin was also
Table $6{ }^{13} \mathrm{C}:{ }^{12} \mathrm{C}$ ratio in salicin from Populus trichocarpa early in the growing season. Tissue type, time after labeling, and the mechanical damage treatment (early season damage, late season damage, and no damage) were included in fully crossed mixed models. The best-fit models are presented

\begin{tabular}{lrlc}
\hline & $F$ & $\mathrm{df}$ & $P$ \\
\hline Early season (AIC = -1417.3) & & & \\
$\quad$ Tissue & 18.3 & $3 / 20.6$ & $<0.0001$ \\
$\quad$ Mechanical damage & 4.2 & $1 / 18.5$ & 0.056 \\
$\begin{array}{l}\text { Late season (AIC = -1015.0) } \\
\quad \text { Tissue }\end{array}$ & 11.2 & $2 / 33.5$ & 0.0002 \\
\hline
\end{tabular}

AIC, Akaike information criterion.

slower and peaked at 1 month post-labeling. Late in the growing season, ${ }^{13} \mathrm{C}$ incorporation into salicin only differed with the type of tissue, being overall highest in leaves and lowest in roots (Table 6; Fig. 3b).

Salicortin Similar to salicin, salicortin had the highest incorporation of label $\mathrm{C}$ in immature leaves, and more label was allocated to salicortin $6 \mathrm{~h}$ after labeling with mechanical damage (Table 7; Fig. 4a). The presence of ${ }^{13} \mathrm{C}$ in immature leaves from plants with damage dropped quickly, however, and was higher in plants without damage at $24 \mathrm{~h}$ post-labeling. The amount of label $\mathrm{C}$ in salicortin from mature leaves peaked at $1 \mathrm{wk}$ after labeling with mechanical damage, but it peaked in mature leaves without damage at 1 month after labeling. The opposite was true for bark there was more ${ }^{13} \mathrm{C}$ in salicortin extracted from the bark of plants without damage $1 \mathrm{wk}$ after labeling, whereas more ${ }^{13} \mathrm{C}$ was measured in salicortin from the bark of plants with damage 1 month after labeling. Late in the growing season, ${ }^{13} \mathrm{C}$ incorporation into salicortin also only differed with the type of tissue, again being highest in leaves and lowest in roots (Table 7; Fig. 4b).

Additional analyses examining potential differences in ${ }^{13} \mathrm{C}$ incorporation in leaf metabolites and bulk tissue as a result of the location of the leaf relative to the site of mechanical damage

Table $7{ }^{13} \mathrm{C}:{ }^{12} \mathrm{C}$ ratio in salicortin from Populus trichocarpa. Tissue type, time after labeling, and the mechanical damage treatment (early-season damage, late-season damage, and no damage) were included in fully crossed mixed models. The best-fit models are presented

\begin{tabular}{lrll}
\hline & $F$ & $\mathrm{df}$ & $P$ \\
\hline Early season (AIC =-960.5) & & & \\
$\quad$ Tissue & 14.1 & $3 / 33$ & $<0.0001$ \\
Mechanical damage & 0.3 & $1 / 25.1$ & 0.6 \\
Time & 0.7 & $3 / 20.6$ & 0.6 \\
Tissue $\times$ damage & 0.4 & $3 / 33$ & 0.7 \\
Tissue $\times$ time & 2.9 & $8 / 49.3$ & 0.01 \\
Damage $\times$ time & 2.1 & $3 / 20.6$ & 0.1 \\
Tissue $\times$ damage $\times$ time & 3.4 & $8 / 49.3$ & 0.002 \\
Late season (AIC=-491.8) & & & \\
$\quad$ Tissue & 4.7 & $2 / 32.8$ & 0.02 \\
\hline
\end{tabular}

AIC, Akaike information criterion. 
(above, below, on a separate branch) did not reveal significant responses to the damage treatment.

\section{Metabolite turnover - understanding metabolite production over time}

Fast and slow turnover times were detected for all metabolites by calculating turnover based on the fraction ${ }^{13} \mathrm{C}$ content in sugars and salicinoids over the first $24 \mathrm{~h}$ post-labeling (fast) and over the course of 1 month (early season, slow) or 2 wk (late season, slow) post-labeling (Table 8,9$)$. The following results describe the fast turnover responses; there were no significant differences between tissues or with mechanical damage for slow turnover times. Sucrose turnover was faster by far than all other metabolites measured. In immature leaves, sucrose turned over in $<2 \mathrm{~h}$; turnover was $<5 \mathrm{~h}$ in mature leaves and c. $22 \mathrm{~h}$ in bark and $65 \mathrm{~h}$ in roots. Sucrose turnover was also affected by mechanical damage and was faster in plants with damage (Table S1).

Similar to sucrose, turnover of glucose differed with tissue type, being faster in immature leaves $(c .17 \mathrm{~h})$ than in mature leaves $(c .30 \mathrm{~h})$ or bark $(c .34 \mathrm{~h})$ and roots $(c .46 \mathrm{~h})$. Mechanical damage was not important for glucose turnover (Table S1). Fructose turnover was very similar to glucose and also differed with tissue type but not damage (Table S1).

Salicin turnover did not differ with tissue type or mechanical damage early in the growing season. Fast turnover of salicin in leaves was $c .19 \mathrm{~h}$, and slow turnover was $c .32 \mathrm{~d}$. Salicortin turnover varied with tissue type over the first $24 \mathrm{~h}$ post-labeling, being

Table 8 Mean fast and slow turnover times (h) for sugars and phenolic glycosides extracted from Populus trichocarpa early in the growing season. Sample sizes are in parentheses. Statistical differences are presented in Tables S1 and S2

\begin{tabular}{|c|c|c|c|c|c|c|}
\hline \multirow[b]{2}{*}{ Metabolite } & \multirow[b]{2}{*}{ Tissue } & \multirow{2}{*}{$\begin{array}{l}\text { Mechanical } \\
\text { damage }\end{array}$} & \multicolumn{2}{|l|}{ Fast turnover } & \multicolumn{2}{|l|}{ Slow turnover } \\
\hline & & & Turnover time & SE & Turnover time & SE \\
\hline \multirow[t]{8}{*}{ Sucrose } & \multirow[t]{2}{*}{ Immature leaves } & Early season & $0.4(6)$ & 1.1 & $113.7(1)$ & \\
\hline & & No damage & $3.2(3)$ & 4.6 & $80.6(1)$ & \\
\hline & \multirow[t]{2}{*}{ Mature leaves } & Early season & $0.1(6)$ & 0.9 & $114.0(6)$ & 17.8 \\
\hline & & No damage & $9.5(3)$ & 10.6 & $112.6(3)$ & 22.6 \\
\hline & \multirow[t]{2}{*}{ Bark } & Early season & $8.3(3)$ & 1.2 & $231.3(3)$ & 33.7 \\
\hline & & No damage & $36.6(3)$ & 22.1 & $56.4(2)$ & 32.7 \\
\hline & \multirow[t]{2}{*}{ Roots } & Early season & $57.3(3)$ & 21.4 & $330.7(3)$ & 181.4 \\
\hline & & No damage & $72.6(2)$ & 13.7 & $235.3(3)$ & 110.9 \\
\hline \multirow[t]{8}{*}{ Glucose } & \multirow[t]{2}{*}{ Immature leaves } & Early season & $18.0(6)$ & 3.1 & $179.9(1)$ & 859.7 \\
\hline & & No damage & $15.6(3)$ & 3.3 & $197.7(1)$ & \\
\hline & \multirow[t]{2}{*}{ Mature leaves } & Early season & $24.1(6)$ & 4.6 & $243.7(6)$ & 18.5 \\
\hline & & No damage & $36.5(3)$ & 16.5 & $182.2(2)$ & 90.5 \\
\hline & \multirow[t]{2}{*}{ Bark } & Early season & $23.4(3)$ & 6.6 & $296.1(3)$ & 23.3 \\
\hline & & No damage & $44.8(2)$ & 18.7 & $191.6(3)$ & 12.6 \\
\hline & \multirow[t]{2}{*}{ Roots } & Early season & $33.7(3)$ & 9.4 & $476.8(3)$ & 154.6 \\
\hline & & No damage & $57.6(3)$ & 17.2 & $314.1(3)$ & 149.9 \\
\hline \multirow[t]{8}{*}{ Fructose } & \multirow[t]{2}{*}{ Immature leaves } & Early season & $17.6(6)$ & 1.9 & $262.6(1)$ & 298.0 \\
\hline & & No damage & $13.2(3)$ & 0.9 & $223.2(2)$ & 49.5 \\
\hline & \multirow[t]{2}{*}{ Mature leaves } & Early season & $22.8(6)$ & 2.0 & $314.1(6)$ & 21.2 \\
\hline & & No damage & $25.9(3)$ & 9.1 & $417.2(3)$ & 81.6 \\
\hline & \multirow[t]{2}{*}{ Bark } & Early season & $28.4(3)$ & 5.3 & $316.1(3)$ & 28.9 \\
\hline & & No damage & $33.8(3)$ & 6.5 & $317.2(2)$ & 61.6 \\
\hline & \multirow[t]{2}{*}{ Roots } & Early season & $73.0(1)$ & & $399.6(2)$ & 54.4 \\
\hline & & No damage & & & $255.2(1)$ & \\
\hline \multirow[t]{8}{*}{ Salicin } & \multirow[t]{2}{*}{ Immature leaves } & Early season & $13.8(3)$ & 3.4 & $643.4(1)$ & \\
\hline & & No damage & $22.9(2)$ & 1.5 & $360.4(2)$ & 117.7 \\
\hline & \multirow[t]{2}{*}{ Mature leaves } & Early season & $20.5(5)$ & 2.8 & $1211.7(5)$ & 256.9 \\
\hline & & No damage & $17.9(3)$ & 2.0 & $892.0(2)$ & 115.0 \\
\hline & \multirow[t]{2}{*}{ Bark } & Early season & $27.6(1)$ & & $670.8(3)$ & 82.0 \\
\hline & & No damage & $18.8(1)$ & & $802.3(2)$ & 176.8 \\
\hline & \multirow[t]{2}{*}{ Roots } & Early season & & 878.1 & & \\
\hline & & No damage & & 498.5 & & \\
\hline Salicortin & Immature leaves & Early season & $10.9(6)$ & 1.9 & $568.2(1)$ & \\
\hline & & No damage & $21.1(3)$ & 2.6 & $464.3(1)$ & \\
\hline & Mature leaves & Early season & $18.0(6)$ & 2.8 & $1013.3(6)$ & 192.3 \\
\hline & & No damage & $17.5(3)$ & 1.8 & $1270.0(3)$ & 52.4 \\
\hline & Bark & Early season & $22.0(3)$ & 2.9 & $842.4(3)$ & 102.0 \\
\hline & & No damage & $22.8(3)$ & 2.6 & $735.3(3)$ & 23.6 \\
\hline & Roots & Early season & & & $1003.0(1)$ & \\
\hline & & No damage & & & $470.8(1)$ & \\
\hline
\end{tabular}


Table 9 Mean fast and slow turnover times (h) for phenolic glycosides extracted from Populus trichocarpa late in the growing season. Sample sizes are in parentheses. Statistical differences are presented in Table S3

\begin{tabular}{|c|c|c|c|c|c|c|}
\hline \multirow[b]{2}{*}{ Metabolite } & \multirow[b]{2}{*}{ Tissue } & \multirow{2}{*}{$\begin{array}{l}\text { Mechanical } \\
\text { damage }\end{array}$} & \multicolumn{2}{|l|}{ Fast turnover } & \multicolumn{2}{|l|}{ Slow turnover } \\
\hline & & & Turnover time & SE & Turnover time & SE \\
\hline \multirow[t]{9}{*}{ Salicin } & \multirow[t]{3}{*}{ Mature leaves } & Early season & $11.5(3)$ & 2.3 & $472.0(3)$ & 19.8 \\
\hline & & Late season & $19.8(2)$ & 2.6 & $323.7(2)$ & 31.0 \\
\hline & & No damage & $12.7(2)$ & 1.6 & $349.4(2)$ & 89.4 \\
\hline & \multirow[t]{3}{*}{ Bark } & Early season & $16.4(3)$ & 2.0 & $386.6(3)$ & 46.2 \\
\hline & & Late season & $21.3(3)$ & 1.8 & $353.4(3)$ & 35.1 \\
\hline & & No damage & $16.2(2)$ & 2.3 & 364.5 (3) & 64.4 \\
\hline & \multirow[t]{3}{*}{ Roots } & Early season & $12.8(2)$ & 2.8 & 384.1 (3) & 5.5 \\
\hline & & Late season & $22.7(1)$ & & 333.2 (3) & 17.0 \\
\hline & & No damage & $21.3(2)$ & 3.2 & 368.9 (3) & 88.5 \\
\hline \multirow[t]{9}{*}{ Salicortin } & \multirow[t]{3}{*}{ Mature leaves } & Early season & $10.5(3)$ & 2.8 & $628.9(2)$ & 153.9 \\
\hline & & Late season & $25.3(2)$ & 1.1 & $260.9(3)$ & 33.9 \\
\hline & & No damage & $12.2(2)$ & 2.9 & $622.2(2)$ & 305.9 \\
\hline & \multirow[t]{3}{*}{ Bark } & Early season & $18.4(3)$ & 2.0 & 334.8 (3) & 16.5 \\
\hline & & Late season & $18.9(3)$ & 1.9 & $348.3(3)$ & 31.6 \\
\hline & & No damage & $14.6(3)$ & 1.5 & $424.4(3)$ & 32.9 \\
\hline & \multirow[t]{3}{*}{ Roots } & Early season & $18.6(3)$ & 1.7 & 396.0 (3) & 66.1 \\
\hline & & Late season & $21.2(2)$ & 2.9 & $403.5(3)$ & 35.5 \\
\hline & & No damage & $17.2(2)$ & 1.2 & 392.0 (3) & 52.1 \\
\hline
\end{tabular}

slower in bark $(c .22 \mathrm{~h})$ than in mature or immature leaves (c. $17 \mathrm{~h}$; Table S2). Slow salicortin turnover in leaves was also similar to salicin $-c .34 \mathrm{~d}$. Late in the growing season, the mechanical damage treatment affected the fast turnover of both salicin and salicortin, and plants with late-season damage had the slowest salicinoid turnover times (Table S3).

\section{Discussion}

Examination of the allocation of newly assimilated $\mathrm{C}$ to primary and defensive secondary metabolites over time in conjunction with a mechanical damage treatment allowed several related hypotheses to be addressed simultaneously, providing a detailed picture of potential tradeoffs in growth and defense and changes in defense production with phenology and tissue loss.

Our first hypothesis predicted that early-season defense production might rely on stored $\mathrm{C}$ to diminish potential tradeoffs between growth and defense. The GDBH states that this tradeoff occurs when resources are at moderate to high quantities (Herms \& Mattson, 1992). The predicted tradeoff is often (Wilkens etal., 1996; Glynn etal., 2003, 2007; Barton \& Koricheva, 2010), but not always, found (Riipi et al., 2002; Barto \& Cipollini, 2005; Massad etal., 2012). The GDBH is generally tested by contrasting whole-plant growth with defense production, but monitoring newly assimilated $\mathrm{C}$ allocation allowed us to determine specifically whether individual plant tissues can produce defenses while developing. Our ${ }^{13} \mathrm{C}$ data showed that newly assimilated C was directly allocated to defense, even as leaves were developing. This was unexpected because salicinoids are considered costly in the related $P$. tremuloides (Osier \& Lindroth, 2006). However, the negative correlations between salicinoids and growth in P.tremuloides were only present under low resource conditions (Osier \& Lindroth, 2006), and our experimental growing conditions may have been too benign to lead to tradeoffs between primary and secondary metabolism.

Within a plant, defense is often highest in young leaves in spite of the hypothesized restrictions on secondary metabolite production in developing tissues (Kursar \& Coley, 2003; Brenes-Arguedas et al., 2006), probably because immature leaves are especially vulnerable to herbivores (Coley, 1983; Coley \& Barone, 1996), and their long-term photosynthetic potential makes them of high value to a plant (as per the ODH, McKey, 1974; Rhoades, 1979). Our second hypothesis predicted that salicinoid concentrations would therefore be highest in young leaves. Concentrations of salicin were in fact highest in immature leaves early in the growing season (early growing season concentration $\approx 0.004 \mathrm{mg} \mathrm{mg}^{-1}$ ), when leaves offered the greatest potential for future $\mathrm{C}$ gain. A similar pattern was found for phenolics isolated from Betula pubescens (Riipi et al., 2002). Our data showed that salicortin concentrations were highest in mature leaves. Glynn et al. (2007) documented equal concentrations of salicortin in immature and mature leaves but higher concentrations of salicin in immature leaves of Salix, and total salicinoids from Populus nigra were found to be higher in younger leaves (Boeckler et al., 2013). These results highlight the simultaneous importance of growth and defense to a plant, but in conjunction with the ${ }^{13} \mathrm{C}$ data described earlier, they suggest that defense is prioritized in growing tissues, as newly assimilated $\mathrm{C}$ was immediately invested in salicinoids in immature leaves.

We cannot rule out the possibility that salicinoids were produced in mature leaves and translocated to developing tissues, but the rapid inclusion of label $\mathrm{C}$ in salicin and salicortin isolated from immature leaves, which was far greater than the incorporation of label $\mathrm{C}$ in defenses in mature leaves, supports the conclusion that salicinoids are produced in immature leaves. In addition, in damaged plants early in the growing season, we 
found a faster turnover time in salicinoids from immature leaves than from mature leaves (c. 12 vs $19 \mathrm{~h}$ ). Lastly, the increase in glucose in immature leaves at $24 \mathrm{~h}$ post-damage further suggests that salicinoids are synthesized in immature leaves, because glucose forms the carbohydrate moiety of both salicin and salicortin.

Concentrations of salicin and salicortin differed in their support of the hypothesis that defenses would decline over the course of the growing season. Salicin decreased in all tissues during the experiment. By contrast, concentrations of salicortin were relatively constant in leaves throughout the growing season, and salicortin concentrations increased in bark late in the season (early $=0.012 \pm 3.6 \times 10^{-4} \mathrm{mg} \mathrm{mg}^{-1}$,

late $=0.014 \pm 7.5 \times 10^{-4} \mathrm{mg} \mathrm{mg}^{-1}$ ). Salicortin is thought to function against mammalian browsing during the winter (Bailey et al., 2007; Lindroth et al., 2007), perhaps explaining its higher concentration in bark late in the season. Other work has shown that seasonal changes in salicin and salicortin vary between genotypes, but similarly, an overall decrease in salicin and an increase in salicortin have been measured (Osier et al., 2000).

Turnover in defense production was also tested, and salicinoids were found to be continuously produced throughout the growing season, even as total concentrations of salicin declined in leaves. Our calculations of fast turnover early in the growing season showed that salicin and salicortin turned over roughly every $20 \mathrm{~h}$ in leaves, except in immature leaves with mechanical damage where turnover was much faster $(c .14 \mathrm{~h}$ for salicin and $11 \mathrm{~h}$ for salicortin). A slower turnover time was also calculated beyond $24 \mathrm{~h}$ post-labeling. This indicates internal $\mathrm{C}$ cycling, which is further supported by delayed spikes in ${ }^{13} \mathrm{C}$ in respired $\mathrm{CO}_{2}$ at 144 and $240 \mathrm{~h}$ after the early-season labeling (Fig. S5a). Other labeling studies have likewise documented internal $\mathrm{C}$ cycling by showing multiple peaks in the respiration of labeled $\mathrm{C}$ over time (Bahn et al., 2010) or by measuring variation in the turnover time of labeled $\mathrm{C}$, suggesting the existence of fast, intermediate, and storage $\mathrm{C}$ pools (Carbone \& Trumbore, 2007).

Our measurements of both salicinoid concentrations and isotope ratios clarify the discrepancy that exists between Kleiner et al.'s (1999) and Ruuhola \& Julkunen-Tiitto's (2000) datasets on turnover. Ruuhola et al. found no evidence for turnover of salicinoids in Salix myrsinifolia based on concentrations of metabolites in phenylalanine ammonia-lyase inhibited plants. Concentration data alone may not be sufficient to answer questions of turnover, however, if both production and loss are inhibited after initial synthesis (Ruuhola et al. also showed a slight loss of salicortin in mature leaves and stems of plants whose salicinoid synthesis was blocked). Similar to our results, ${ }^{14} \mathrm{C}$ labeling in $P$. tremuloides demonstrated that the $\mathrm{C}$ in salicinoids is replaced over a period of days (Kleiner et al., 1999). Our isotope data showed that after labeling early in the growing season, ${ }^{13} \mathrm{C}$ increased rapidly in salicin and salicortin from leaves and declined after $1 \mathrm{wk}$ (with the exception of ${ }^{13} \mathrm{C}$ in salicortin from mature leaves of plants without damage, which increased over a month). We also showed that concentrations of salicinoids were not increasing with time, confirming that turnover rather than an accumulation of defense compounds is responsible for the observed dilution in isotope levels. Turnover increases the costs of secondary metabolites in terms of resources required for substrates and biosynthetic machinery, and this continual investment further suggests the ecological value of these compounds to plants.

Some of the decline in labeled salicinoids in leaves in our work might be explained by the export of a portion to bark and roots, as the presence of ${ }^{13} \mathrm{C}$ increased with time in salicin and salicortin isolated from these tissues. Salicinoids may have been synthesized in bark and roots directly, but the delay in the appearance of the label in salicin and salicortin relative to sugars suggests that the compounds were transported from leaves. Salicinoid biosynthesis and transport are areas that still require further research (Babst et al., 2010; Boeckler et al., 2011).

Our last hypothesis predicted that salicinoids would be inducible early in the growing season. The mechanical damage treatment was able to induce higher production of salicin, but not salicortin, after $24 \mathrm{~h}$. This response was found across leaf ages, although mature leaves were able to induce salicin production more quickly, suggesting there may have been resource limitation in immature leaves that were still expanding and lignifying. In a study with Salix sericea, salicortin concentrations actually declined in damaged leaves (Fields \& Orians, 2006). This result is similar to our data documenting higher concentrations of salicortin from leaves of undamaged plants, and Fields \& Orians (2006) speculated that salicortin may be degraded after leaf damage. Our ${ }^{13} \mathrm{C}$ data support this conclusion because, although concentrations of salicortin did not increase following damage, more ${ }^{13} \mathrm{C}$ was measured in salicortin from damaged plants. A faster early-season turnover time was also calculated for salicortin from immature leaves of damaged plants $(c .10 \mathrm{~h})$ than for salicortin from immature leaves of undamaged plants $(c .21 \mathrm{~h})$. In $P$. tremuloides, mechanical damage mimicking caterpillar feeding increased concentrations of salicortin but not those of salicin. It was also found that further crushing of leaf tissue to mimic caterpillar chewing caused a conversion of salicortin to salicin (Clausen etal., 1989). A similar reaction may have occurred in our samples, accounting for the higher salicortin concentrations in undamaged plants and higher salicin concentrations in plants with damage; this is again supported by the isotope data showing a higher inclusion of label $\mathrm{C}$ in salicortin despite the lack of change in the overall concentration. Clausen et al. (1989) also proposed that increased salicortin concentrations following damage were potentially the result of a translocation of salicortin from the internodes to the leaves. The rapid inclusion of ${ }^{13} \mathrm{C}$ in salicortin that we found contradicts this theory, however, and points to a de novo synthesis following damage.

In conclusion, our study contributes to an improved understanding of several important issues in the ecology of plant chemical defenses. We have shown that, in P. trichocarpa, growth and defense are both prioritized in developing tissues, supporting predictions of the $\mathrm{ODH}$ and other studies demonstrating high defenses in young leaves. Our use of an isotope tracer showed that the fast-growing $P$. trichocarpa invests new assimilates in growth and defense at the same time. Another factor that could increase the allocation costs of defense in this species is the rapid turnover of salicinoids. The fact that labeled carbon is allocated to salicinoids in both immature and mature tissues throughout a 
growing season highlights their value (salicortin DW can be $10 \%$ of leaf mass; Orians \& Fritz, 1995) to the plant and the importance of defense.

\section{Acknowledgements}

We gratefully acknowledge the excellent support from colleagues at the Max Planck Institutes for Biogeochemistry and Chemical Ecology who made this work possible, including Agnes Fastnacht, Heike Geilmann, Olaf Kolle, Karl Kübler, Iris Kuhlman, Petra Linke, and Beate Rothe. We would also like to thank Torsten Frosch and Robert Keiner of the Institute of Photonic Technology for assistance in gas monitoring and use of their Raman spectrometer. Thank you to the Thüringer Landesanstalt für Landwirtschaft for providing P. trichocarpa cuttings. This work was supported by the Max Planck Institutes for Biogeochemistry and Chemical Ecology. Finally, we would like to thank three anonymous reviewers for their helpful comments on the manuscript.

\section{References}

Agrawal AA, Conner JK, Johnson MTJ, Wallsgrove R. 2002. Ecological genetics of an induced plant defense against herbivores: additive genetic variance and costs of phenotypic plasticity. Evolution 56: 2206-2213.

Babst BA, Harding SA, Tsai C-J. 2010. Biosynthesis of phenolic glycosides from phenylpropanoid and benzenoid precursors in Populus. Journal of Chemical Ecology 36: 286-297.

Bahn M, Janssens IA, Reichstein M, Smith P, Trumbore SE. 2010. Soil respiration across scales: towards an integration of patterns and processes. New Phytologist 186: 292-296.

Bailey JK, Schweitzer JA, Rehill BJ, Irschick DJ, Whitham TG, Lindroth RL. 2007. Rapid shifts in the chemical composition of aspen forests: an introduced herbivore as an agent of natural selection. Biological Invasions 9: 715-722.

Baldwin I, Karb M, Ohnmeiss T. 1994. Allocation of ${ }^{15} \mathrm{~N}$ from nitrate to nicotine - production and turnover of a damage-induced mobile defense. Ecology 75: 1703-1713.

Barto EK, Cipollini D. 2005. Testing the optimal defense theory and the growth-differentiation balance hypothesis in Arabidopsis thaliana. Oecologia 146: 169-178.

Barton KE, Koricheva J. 2010. The ontogeny of plant defense and herbivory: characterizing general patterns using meta-analysis. American Naturalist 175: 481-493.

Boeckler GA, Gershenzon J, Unsicker SB. 2011. Phenolic glycosides of the Salicaceae and their role as anti-herbivore defenses. Phytochemistry 72: 1497-1509.

Boeckler GA, Gershenzon J, Unsicker SB. 2013. Gypsy moth caterpillar feeding has only a marginal impact on phenolic compounds in old-growth black poplar. Journal of Chemical Ecology 39: 1301-1312.

Brenes-Arguedas T, Horton MW, Coley PD, Lokvam J, Waddell RA, Meizoso-O'Meara BE, Kursar TA. 2006. Contrasting mechanisms of secondary metabolite accumulation during leaf development in two tropical tree species with different leaf expansion strategies. Oecologia 149: 91-100.

Bryant JP. 1981. Phytochemical deterrence of snowshoe hare browsing by adventitious shoots of four Alaskan trees. Science 213: 889-890.

Bryant JP, Tuomi J, Niemala P. 1988. Environmental constraints of constitutive and long-term inducible defenses in woody plants. In: Spencer K, ed. Chemical mediation of coevolution. Philadelphia, PA, USA: Academic Press, 367-389.

Carbone MS, Trumbore SE. 2007. Contribution of new photosynthetic assimilates to respiration by perennial grasses and shrubs: residence times and allocation patterns. New Phytologist 176: 124-135.

Clausen T, Reichardt P, Bryant J, Werner R, Post K, Frisby K. 1989. Chemical model for short-term induction in quaking aspen (Populus tremuloides) foliage against herbivores. Journal of Chemical Ecology 15: 2335-2346.
Coley P. 1983. Herbivory and defensive characteristics of tree species in a lowland tropical forest. Ecological Monographs 53: 209-233.

Coley P. 1986. Costs and benefits of defense by tannins in a neotropical tree. Oecologia 70: 238-241.

Coley PD, Barone JA. 1996. Herbivory and plant defenses in tropical forests. Annual Review of Ecology and Systematics 27: 305-335.

Donaldson JR, Kruger EL, Lindroth RL. 2006. Competition- and resource-mediated tradeoffs between growth and defensive chemistry in trembling aspen (Populus tremuloides). New Phytologist 169: 561-570.

Fields MJ, Orians CM. 2006. Specificity of phenolic glycoside induction in willow seedlings (Salix sericea) in response to herbivory. Journal of Chemical Ecology 32: 2647-2656.

Fox J, Weisberg S, Adler D, Bates D, Baud-Bovy G, Ellison S, Firth D, Friendly M, Gorjanc G, Graves S et al. 2013. Package Car. [WWW document] URL https://r-forge.r-project.org/projects/car/,http://CRAN.R-project.org/ package $=$ car [accessed 14 September 2013].

Frosch T, Keiner R, Michalzik B, Fischer B, Popp J. 2013. Investigation of gas exchange processes in peat bog ecosystems by means of innovative Raman gas spectroscopy. Analytical Chemistry 85: 1295-1299.

Gershenzon J. 1994. The cost of plant chemical defense against herbivory: a biochemical perspective. In: Bernays EA, ed. Insect-plant interactions. Boca Raton, FL, USA: CRC Press, 105-173.

Gershenzon J, Dudareva N. 2007. The function of terpene natural products in the natural world. Nature Chemical Biology 3: 408-414.

Gershenzon J, Murtagh G, Croteau R. 1993. Absence of rapid terpene turnover in several diverse species of terpene-accumulating plants. Oecologia 96: 583-592.

Glynn C, Herms DA, Egawa M, Hansen R, Mattson WJ. 2003. Effects of nutrient availability on biomass allocation as well as constitutive and rapid induced herbivore resistance in poplar. Oikos 101: 385-397.

Glynn C, Herms DA, Orians CM, Hansen RC, Larsson S. 2007. Testing the growth-differentiation balance hypothesis: dynamic responses of willows to nutrient availability. New Phytologist 176: 623-634.

Harding SA, Jarvie MM, Lindroth RL, Tsai C-J. 2009. A comparative analysis of phenylpropanoid metabolism, $\mathrm{N}$ utilization, and carbon partitioning in fastand slow-growing Populus hybrid clones. Journal of Experimental Botany 60: 3443-3452.

Hare JD, Elle E, van Dam NM. 2003. Costs of glandular trichomes in Datura wrightii: a three-year study. Evolution 57: 793-805.

Herms D, Mattson W. 1992. The dilemma of plants - to grow or defend. Quarterly Review of Biology 67: 283-335.

Hettmann E, Brand WA, Gleixner G. 2007. Improved isotope ratio measurement performance in liquid chromatography/isotope ratio mass spectrometry by removing excess oxygen. Rapid Communications in Mass Spectrometry 21: 4135-4141.

Holeski LM, Hillstrom ML, Whitham TG, Lindroth RL. 2012. Relative importance of genetic, ontogenetic, induction, and seasonal variation in producing a multivariate defense phenotype in a foundation tree species. Oecologia 170: 695-707.

Hwang SY, Lindroth RL. 1997. Clonal variation in foliar chemistry of aspen: effects on gypsy moths and forest tent caterpillars. Oecologia 111: 99-108.

Keeling CD. 1958. The concentration and isotopic abundance of atmospheric carbon dioxide in rural areas. Geochimica et Cosmochimica Acta 13: 322-334.

Kleiner KW, Ellis DD, McCown BH, Raffa KF. 2003. Leaf ontogeny influences leaf phenolics and the efficacy of genetically expressed Bacillus thuringiensis cry1A(a) d-endotoxin in hybrid poplar against gypsy moth. Journal of Chemical Ecology 29: 2585-2602.

Kleiner KW, Raffa KF, Dickson RE. 1999. Partitioning of ${ }^{14} \mathrm{C}$-labeled photosynthate to allelochemicals and primary metabolites in source and sink leaves of aspen: evidence for secondary metabolite turnover. Oecologia 119: 408-418.

Koricheva J. 2002. Meta-analysis of sources of variation in fitness costs of plant antiherbivore defenses. Ecology 83: 176-190.

Kosola KR, Dickmann DI, Parry D. 2002. Carbohydrates in individual poplar fine roots: effects of root age and defoliation. Tree Physiology 22: 741-746.

Kursar TA, Coley PD. 2003. Convergence in defense syndromes of young leaves in tropical rainforests. Biochemical Systematics and Ecology 31: 929-949. 
Lindroth RL, Donaldson JR, Stevens MT, Gusse AC. 2007. Browse quality in quaking aspen (Populus tremuloides): effects of genotype, nutrients, defoliation, and coppicing. Journal of Chemical Ecology 33: 1049-1064.

Lindroth RL, St Clair SB. 2013. Adaptations of quaking aspen (Populus tremuloides Michx.) for defense against herbivores. Forest Ecology and Management 299: 14-21.

Massad TJ, Dyer LA, Vega GC. 2012. Costs of defense and a test of the carbon-nutrient balance and growth-differentiation balance hypotheses for two co-occurring classes of plant defense. PLoS ONE 7: e47554.

McKey D. 1974. Adaptive patterns in alkaloid physiology. American Naturalist 108: 305-320.

Meyer G, Montgomery M. 1987. Relationships between leaf age and the food quality of cottonwood foliage for the gypsy moth, Lymantria dispar. Oecologia 72: 527-532.

Mihaliak C, Gershenzon J, Croteau R. 1991. Lack of rapid monoterpene turnover in rooted plants - Implications for theories of plant-chemical defense. Oecologia 87: 373-376.

Mooney HA, Chu C. 1974. Seasonal carbon allocation in Heteromeles arbutifolia, a California evergreen shrub. Oecologia 14: 295-306.

Neilson EH, Goodger JQD, Woodrow IE, Moller BL. 2013. Plant chemical defense: at what cost? Trends in Plant Science 18: 250-258.

Orians CM, Fritz RS. 1995. The effects of hybridization between two Salix species on foliar chemistry. Journal of Chemical Ecology 21: 1245-1253.

Osier TL, Hwang SY, Lindroth RL. 2000. Within- and between-year variation in early season phytochemistry of quaking aspen (Populus tremuloides Michx.) clones. Biochemical Systematics and Ecology 28: 197-208.

Osier TL, Lindroth RL. 2001. Effects of genotype, nutrient availability, and defoliation on aspen phytochemistry and insect performance. Journal of Chemical Ecology 27: 1289-1313.

Osier TL, Lindroth RL. 2006. Genotype and environment determine allocation to and costs of resistance in quaking aspen. Oecologia 148: 293-303.

Qi HP, Coplen TB, Geilmann H, Brand WA, Bohlke JK. 2003. Two new organic reference materials for $\delta^{13} \mathrm{C}$ and $\delta^{15} \mathrm{~N}$ measurements and a new value for the $\delta^{13} \mathrm{C}$ of NBS 22 oil. Rapid Communications in Mass Spectrometry 17: 2483-2487.

Redman AM, Cipollini DF, Schultz JC. 2001. Fitness costs of jasmonic acid-induced defense in tomato, Lycopersicon esculentum. Oecologia 126: 380-385.

Rhoades DF. 1979. Evolution of plant chemical defenses against herbivory. In: Rosenthal GA, Janzen DH, eds. Herbivores: their interaction with secondary plant metabolites. New York, NY, USA: Academic Press, 3-54.

Richter A, Wanek W, Werner RA, Ghashghaie J, Jaeggi M, Gessler A, Brugnoli E, Hettmann E, Gottlicher SG, Salmon Y et al. 2009. Preparation of starch and soluble sugars of plant material for the analysis of carbon isotope composition: a comparison of methods. Rapid Communications in Mass Spectrometry 23: 2476-2488.

Riipi M, Ossipov V, Lempa K, Haukioja E, Koricheva J, Ossipova S, Pihlaja K. 2002. Seasonal changes in birch leaf chemistry: are there trade-offs between leaf growth, and accumulation of phenolics? Oecologia 130: 380-390.

Ruuhola TM, Julkunen-Tiitto MRK. 2000. Salicylates of intact Salix myrsinifolia plantlets do not undergo rapid metabolic turnover. Plant Physiology 122: 895-905.

Ruuhola TM, Sipura M, Nousiainen O, Tahvanainen J. 2001. Systemic induction of salicylates in Salix myrsinifolia (Salisb.). Annals of Botany 88: 483-497.

Scheibe A, Krantz L, Gleixner G. 2012. Simultaneous determination of the quantity and isotopic signature of dissolved organic matter from soil water using high-performance liquid chromatography/isotope ratio mass spectrometry. Rapid Communications in Mass Spectrometry 26: 173-180.

Stevens MT, Lindroth RL. 2005. Induced resistance in the indeterminate growth of aspen (Populus tremuloides). Oecologia 145: 298-306.

Strauss SY, Rudgers JA, Lau JA, Irwin RE. 2002. Direct and ecological costs of resistance to herbivory. Trends in Ecology \& Evolution 17: 278-285.

Taiz L, Ziegler E. 2002. Plant physiology, $3^{\text {rd }}$ edn. Sunderland, MA, USA: Sinauer Associates Inc.

Tschaplinski TL, Blake T. 1994. Carbohydrate mobilization following shoot defoliation and decapitation in hybrid poplar. Tree Physiology 14: 141-151.
Wilkens RT, Spoerke JM, Stamp NE. 1996. Differential responses of growth and two soluble phenolics of tomato to resource availability. Ecology 77: 247-258.

Züst T, Joseph B, Shimizu KK, Kliebenstein DJ, Turnbull LA. 2011. Using knockout mutants to reveal the growth costs of defensive traits. Proceedings of the Royal Society B-Biological Sciences 278: 2598-2603.

\section{Supporting Information}

Additional supporting information may be found in the online version of this article.

Fig. S1 Mean ${ }^{13} \mathrm{C}$ incorporation in sucrose extracted from Populus trichocarpa early in the growing season.

Fig. S2 Mean sucrose concentrations in Populus trichocarpa early in the growing season.

Fig. S3 Mean glucose concentrations in Populus trichocarpa early in the growing season.

Fig. S4 Mean fructose concentrations in Populus trichocarpa early in the growing season.

Fig. S5 (a) Mean ${ }^{13} \mathrm{C}$ incorporation in bulk material of Populus trichocarpa early in the growing season; (b) mean ${ }^{13} \mathrm{C}$ incorporation in bulk material of $P$. trichocarpa late in the growing season.

Fig. S6 (a) Mean respired ${ }^{13} \mathrm{C}$ from Populus trichocarpa early in the growing season; (b) mean respired ${ }^{13} \mathrm{C}$ from $P$. trichocarpa late in the growing season.

Fig. S7 Mean ${ }^{13} \mathrm{C}$ incorporation in glucose extracted from Populus trichocarpa early in the growing season.

Fig. S8 Mean ${ }^{13} \mathrm{C}:{ }^{12} \mathrm{C}$ in glucose extracted from Populus trichocarpa early in the growing season.

Fig. S9 Mean ${ }^{13} \mathrm{C}$ incorporation in fructose extracted from Populus trichocarpa early in the growing season.

Table S1 Comparison of the turnover time of sugars extracted from Populus trichocarpa, calculated based on the first $24 \mathrm{~h}$ after the early-season labeling

Table S2 Comparison of the turnover time of salicin and salicortin extracted from Populus trichocarpa, calculated based on the first $24 \mathrm{~h}$ after the early-season labeling

Table S3 Comparison of the turnover time of salicin and salicortin extracted from Populus trichocarpa, calculated based on the first $24 \mathrm{~h}$ after the late-season labeling

Please note: Wiley Blackwell are not responsible for the content or functionality of any supporting information supplied by the authors. Any queries (other than missing material) should be directed to the New Phytologist Central Office. 